\title{
Riwayat paparan pestisida dan kekurangan asupan zat gizi sebagai faktor risiko kejadian anemia pada ibu hamil di daerah pertanian
}

\author{
Sulistyawati $^{1^{*},}$ Ani Margawati ${ }^{1}$, Ali Rosidi ${ }^{2}$, Suhartono $^{3}$
}

\begin{abstract}
Background: Anemia in pregnant women in Brebes Regency, Central Java in 2016 was still high at 60.7\%. Brebes Regency is an area of onion farming with a high intensity of pesticide use.

Objectives: This study aimed to prove the history of pesticide exposure and lack of nutrient intake (iron and vitamin C) was risk factor for the incidence of anemia in pregnant women in agricultural area.

Methods: Case control study with 41 cases (anemia) and 41 controls (non-anemia) as study subjects. The subjects were selected using purposive sampling method. Pesticide exposure history included the involvement of pregnant women in agricultural activities, frequency of exposure and length of exposure was measured by interview using structured questionnaire. Anemia data were obtained by measuring hemoglobin levels. Other independent variables measured were nutritional intake (protein, iron, and vitamin $C$ ) using semi-quantitative food frequency questionnaire (SQ-FFQ) method to determine the level of nutrient adequacy in pregnant women. Data were analyzed using chi-square test and logistic regression.

Result: Hemoglobin levels in the case ranged from $7.2 \mathrm{~g} / \mathrm{dl}$ to $10.9 \mathrm{~g} / \mathrm{dl}$. The results of multivariate logistic regression showed that pesticide exposure history $(O R=4.9,95 \%$ CI:1.75-13.67), level of iron adequacy $(O R=2.9,95 \%$ CI:1.06-8.29) and level of vitamin $C$ adequacy $(O R=3.4,95 \%$ CI:1.10 - 10.28) as risk factors for the incidence of anemia in pregnant women in agricultural area.

Conclusion: The history of pesticide exposure and lack of nutrient intake (iron and vitamin C) was risk factor for the incidence of anemia in pregnant women in agricultural area.
\end{abstract}

Keywords: anemia; agricultural area; pregnant women; pesticide exposure history; nutrient intake

\begin{abstract}
ABSTRAK
Latar Belakang: Anemia pada ibu hamil di Kabupaten Brebes Provinsi Jawa Tengah tahun 2016 masih tinggi yaitu sebesar 60,7\%. Kabupaten Brebes merupakan wilayah pertanian bawang merah dengan intensitas penggunaan pestisida yang tinggi.

Tujuan: Membuktikan riwayat paparan pestisida dan kekurangan asupan zat gizi (protein, zat besi dan vitamin C) sebagai faktor risiko kejadian anemia pada ibu hamil di daerah pertanian.

Metode: Desain penelitian case control dengan jumlah sampel 41 kasus (anemia) dan 41 kontrol (tidak anemia). Pemilihan sampel secara purposive sampling. Riwayat paparan pestisida meliputi keterlibatan ibu hamil dalam kegiatan pertanian, frekuensi paparan dan lama paparan yang diukur dengan wawancara menggunakan kuesioner terstruktur. Data anemia diperoleh melalui pengukuran kadar hemoglobin. Data asupan gizi (protein, zat besi dan vitamin C) dengan metode semiquantitative food frequency questionnaire (SQ-FFQ) untuk mengetahui tingkat kecukupan zat gizi pada ibu hamil. Data dianalisis menggunakan uji chi-square dan regresi logistik.

Hasil: Kadar hemoglobin kelompok kasus sebesar 7,2 g/dl-10,9 g/dl. Hasil uji regresi logistik multivariat menunjukkan bahwa riwayat paparan pestisida (OR=4,9, 95\% CI:1,75-13,67), tingkat kecukupan zat besi (OR=2,9, 95\% CI:1,06-8,29) dan tingkat kecukupan vitamin $C(O R=3,4,95 \%$ CI:1,10-10,28) sebagai faktor risiko kejadian anemia pada ibu hamil di daerah pertanian. Simpulan: Riwayat paparan pestisida dan kekurangan asupan zat besi serta vitamin C merupakan faktor risiko kejadian anemia pada ibu hamil di daerah pertanian.
\end{abstract}

Kata Kunci: anemia; daerah pertanian; ibu hamil; riwayat paparan pestisida; asupan zat gizi

\section{PENDAHULUAN}

Anemia adalah salah satu permasalahan gizi yang terjadi di negara berkembang, termasuk di Indonesia. Anemia mengganggu kesehatan terutama pada wanita dan meningkatkan risiko pada ibu hamil dan bayi yang dilahirkan. World Health Organization (WHO) Tahun
2011 menyatakan bahwa setengah miliar wanita usia subur mengalami anemia, sebesar 29\% (496 juta) terjadi pada wanita tidak hamil dan sebesar $38 \%$ (32,4 juta) terjadi pada wanita hamil berusia 15-49 tahun. Berdasarkan WHO, target penurunan prevalensi anemia pada wanita usia subur sebesar $50 \%$ pada tahun $2025 .{ }^{1}$

\footnotetext{
${ }^{1}$ Departemen Ilmu Gizi, Fakultas Kedokteran, Universitas Diponegoro. Jl. Prof. Sudarto SH, Tembalang, Semarang, Jawa Tengah 50275.

${ }^{2}$ Program Studi Ilmu Gizi, Fakultas Ilmu Keperawatan dan Kesehatan, Universitas Muhammadiyah Semarang. Jl. Kedungmundu Raya No.22 Semarang

${ }^{3}$ Departemen Kesehatan Lingkungan, Fakultas Kesehatan Masyarakat, Universitas Diponegoro. J1. Prof. Sudarto SH, Tembalang, Semarang, Jawa Tengah 50275 .

${ }^{*}$ Korespondensi: E-mail: suliswati991@gmail.com
} 
Berdasarkan data Riskesdas tahun 2013, anemia yang terjadi pada ibu hamil sebanyak $37,1 \% .^{2}$ Anemia pada ibu hamil di Kabupaten Brebes masih tinggi yaitu sebesar $60,7 \% .^{3} \quad$ Ibu hamil yang anemia berisiko mengalami peningkatan angka kesakitan dan kematian ibu, peningkatan angka kesakitan dan kematian bayi, serta peningkatan risiko terjadinya Berat Bayi Lahir Rendah (BBLR). ${ }^{4}$ Kejadian BBLR di Jawa Tengah sebesar 4,42\%, sedangkan di Kabupaten Brebes sebesar $4,44 \% .^{5}$

Anemia pada ibu hamil umumnya disebabkan kekurangan zat besi. Zat besi ini sangat dibutuhkan ibu hamil dalam pembentukan sel darah. Saat kehamilan tubuh mengalami perubahan fisiologis berupa hemodilusi yaitu bertambahnya volume cairan lebih banyak daripada sel darah sehingga kadar hemoglobin berkurang. Hemodilusi mencapai puncaknya pada usia kehamilan 32 minggu, plasma darah volumenya bertambah sebesar 25-30\%. ${ }^{6}$ Kondisi ini mengakibatkan ibu hamil menderita anemia. ${ }^{7}$ Menurut WHO tahun 2008, kadar normal hemoglobin pada ibu hamil sebesar $11 \mathrm{~g} / \mathrm{dl}$, apabila kadar hemoglobin ibu hamil <11 g/dl dinyatakan anemia. ${ }^{8}$ Beberapa zat gizi memiliki peran yang penting dalam pembentukan sel darah merah seperti protein, zat besi, vitamin B12, asam folat, dan vitamin C. ${ }^{9}$ Apabila kekurangan satu atau lebih zat gizi tersebut berpotensi anemia. ${ }^{10}$ Anemia pada kehamilan dapat dicegah apabila seorang ibu memiliki asupan gizi yang baik sebelum dan selama hamil.

Kabupaten Brebes merupakan salah satu daerah di Provinsi Jawa Tengah dengan sumber pendapatan asli pada sektor pertanian terutama bawang merah yang membutuhkan penyemprotan pestisida hingga 2-3 kali per minggu, bahkan setiap hari pada saat musim penghujan. ${ }^{11}$ Sebagian besar petani di Indonesia menggunakan pestisida untuk meningkatkan hasil pertaniannya. ${ }^{12}$ Salah satu kelompok populasi yang berisiko terpapar pestisida yaitu ibu hamil yang berada di daerah pertanian. Hal ini dapat dilihat dari keterlibatan ibu dalam membantu kegiatan pertanian antara lain menanam, membuang rumput dari tanaman, mencari hama, memanen dan melepaskan bawang dari tangkainya. Pestisida yang digunakan dalam pertanian diantaranya adalah pestisida golongan organofosfat. ${ }^{13}$ Pestisida ini termasuk golongan Endocrine Disrupting Chemicals (EDCs) yaitu senyawa-senyawa kimia yang mengganggu sintesis, sekresi, transpor, metabolisme, aksi pengikatan dan penghapusan hormon alami yang berfungsi untuk menjaga homeostasis, reproduksi dan proses tumbuh kembang. ${ }^{14}$

Hasil penelitian pada petani di beberapa desa di India membuktikan bahwa parameter hematologi secara signifikan menurun pada kelompok terpapar pestisida dibandingkan dengan kelompok tidak terpapar pestisida. ${ }^{15}$ Pestisida dapat mengganggu organ pembentukan sel-sel darah yang mengakibatkan abnormalitas pada profil darah. Salah satu dampak pestisida dalam tubuh adalah terjadinya anemia. Anemia dapat terjadi pada orang yang terpapar pestisida golongan organofosfat karena terbentuknya sulfhemoglobin dan methemoglobin di dalam sel darah merah. Sulfhemoglobin terjadi karena kandungan bahan kimia terutama sulfur yang tinggi pada pestisida sehingga menimbulkan ikatan sulfhemoglobin yang menyebabkan daya angkut oksigen oleh hemoglobin menurun. ${ }^{16}$ Hasil penelitian pada petani hortikultura di Kabupaten Pemalang menunjukkan bahwa terdapat hubungan paparan pestisida dengan kejadian anemia, selain itu paparan pestisida mempunyai kecenderungan 5,3 kali lebih besar yang berpengaruh terhadap kejadian anemia bila dibandingkan dengan yang tidak terpapar pestisida, sebab pestisida di dalam tubuh dapat merusak hemoglobin darah sehingga mengakibatkan anemia. ${ }^{17}$ Penelitian terkait paparan pestisida terhadap anemia sudah pernah dilakukan pada petani. Namun, penelitian pada ibu hamil yang terlibat kegiatan pertanian belum pernah dilakukan. Penelitian ini bertujuan untuk membuktikan riwayat paparan pestisida dan kekurangan asupan zat gizi (protein, zat besi dan vitamin C) sebagai faktor risiko kejadian anemia pada ibu hamil yang berada di daerah pertanian Kabupaten Brebes.

\section{BAHAN DAN METODE}

Jenis penelitian ini merupakan penelitian observasional dengan pendekatan case-control. Penelitian dilakukan di wilayah kerja 6 Puskesmas yaitu Puskesmas Wanasari, Puskesmas Bulakamba, Puskesmas Kluwut, Puskesmas Tanjung, Puskesmas Losari dan Puskesmas Kecipir di Kabupaten Brebes Provinsi Jawa Tengah pada bulan Maret sampai Mei 2018. Subjek penelitian ini adalah ibu hamil yang usia kehamilannya 24-40 minggu serta usia ibu hamil 20-35 tahun yang memeriksakan kehamilannya diwilayah kerja 6 Puskesmas tersebut di Kabupaten Brebes yang merupakan daerah pertanian, dengan jumlah sampel 41 kasus (anemia) dan 41 kontrol (tidak anemia).

Pemilihan sampel secara purposive sampling dengan matching tingkat pendidikan ibu hamil. Riwayat paparan pestisida dalam lingkungan sebelum dan selama masa kehamilan meliputi peran serta ibu dalam kegiatan di bidang pertanian yang berisiko adanya paparan pestisida, diberi nilai berdasarkan jumlah kegiatan yang dilakukan dan memperhitungkan lamanya waktu ibu terlibat (jam). Data tersebut diperoleh dari hasil wawancara dan observasi dengan menggunakan kuesioner terstruktur. Dikategorikan terpapar apabila jumlah skor 1-20 dan tidak terpapar apabila jumlah skor 0. Data anemia diperoleh melalui pengukuran kadar hemoglobin melalui darah vena menggunakan alat Sysmex 21 metode cyanide free hemoglobin spectrophotometry. Dikategorikan anemia apabila kadar 
$\mathrm{Hb}<11 \mathrm{~g} / \mathrm{dl}$ dan tidak anemia apabila kadar $\mathrm{Hb} \geq 11$ $\mathrm{g} / \mathrm{dl} .^{8}$ Data asupan zat gizi (protein, zat besi dan vitamin C) melalui wawancara menggunakan semi-quantitative food frequency questionnaire (SQ-FFQ). Jumlah asupan zat gizi dihitung menggunakan program Nutrisurvey 2007. Asupan zat gizi kemudian dibandingkan dengan angka kecukupan gizi (AKG) yang dianjurkan. ${ }^{18}$ Tingkat kecukupan protein dikategorikan kurang apabila asupan $<80 \%$ AKG dan baik apabila asupan $\geq 80 \%$ AKG. Tingkat kecukupan zat besi dan vitamin $\mathrm{C}$ dikategorikan kurang apabila asupan $<77 \%$ AKG dan baik apabila asupan $\geq 77 \%$ AKG. Data dianalisis menggunakan uji chi-square dengan confident interval (CI) 95\%, tingkat kemaknaan ditetapkan dengan nilai $\mathrm{p}<0,05$ dan analisis multivariat dengan regresi logistik.

\section{HASIL}

\section{Gambaran Karakteristik Responden}

Gambaran karakteristik responden meliputi umur responden, umur kehamilan, pendidikan ibu, pekerjaan ibu, pekerjaan kepala keluarga dan tingkat kecukupan protien, zat besi dan vitamin $\mathrm{C}$. Tabel 1 menunjukkan bahwa umur responden terendah dan tertinggi pada kelompok anemia dan tidak anemia sama. Umur terendah responden adalah 20 tahun dan tertinggi 35 tahun. Rata-rata umur kehamilan pada kelompok anemia dan tidak anemia adalah 28 minggu. Umur kehamilan responden tertinggi pada kelompok anemia adalah 38 minggu dan pada kelompok tidak anemia adalah 40 minggu. Rerata tingkat kecukupan protein pada kelompok anemia $(76,11 \%)$ lebih rendah dibanding dengan kelompok tidak anemia (84,14\%). Median tingkat kecukupan zat besi pada kelompok anemia $(25,08 \%)$ lebih rendah dibanding dengan kelompok tidak anemia $(84,14 \%)$. Median tingkat kecukupan vitamin C pada kelompok anemia $(49,96 \%)$ lebih rendah dibanding dengan kelompok tidak anemia $(61,03 \%)$.

Tabel 2 menunjukkan bahwa sebagian besar pendidikan ibu pada kelompok anemia dan kelompok tidak anemia adalah sama yaitu pendidikan tingkat dasar $(78,0 \%)$. Sebagian besar ibu tidak bekerja $(73,2 \%)$ baik pada kelompok anemia maupun pada kelompok tidak anemia. Pekerjaan kepala keluarga sebagai petani pada kelompok anemia $(39,0 \%)$ sedangkan pada kelompok tidak anemia (34,1\%). Hasil penelitian menunjukkan bahwa karakteristik responden yang meliputi umur kehamilan, pendidikan ibu, pekerjaan ibu dan pekerjaan kepala keluarga tidak berbeda bermakna antara kelompok anemia dan kelompok tidak anemia.

Tabel 1. Karakteristik Responden berdasarkan Umur dan Tingkat Kecukupan Gizi antara Kelompok Anemia dan Tidak Anemia

\begin{tabular}{|c|c|c|c|c|c|}
\hline \multirow{3}{*}{ Karakteristik } & \multirow{2}{*}{\multicolumn{2}{|c|}{$\begin{array}{c}\text { Anemia } \\
(n=41) \\
\end{array}$}} & \multirow{2}{*}{\multicolumn{2}{|c|}{$\begin{array}{c}\text { Tidak Anemia } \\
(n=41) \\
\end{array}$}} & \multirow{3}{*}{$p$} \\
\hline & & & & & \\
\hline & $\begin{array}{c}\text { Median } \\
\text { (min, maks) }\end{array}$ & Rerata \pm SD & $\begin{array}{c}\text { Median } \\
\text { (min, maks) }\end{array}$ & Rerata \pm SD & \\
\hline Umur responden (tahun) & $28(20-35)$ & $27,54 \pm 5,31$ & $31(20-35)$ & $30,59 \pm 4,47$ & $0,010^{\mathrm{a}}$ \\
\hline Umur kehamilan (minggu) & $26(24-38)$ & $28,68 \pm 4,66$ & $25(24-40)$ & $28,29 \pm 4,95$ & $0,601^{\mathrm{a}}$ \\
\hline Tingkat kecukupan protein $(\%)$ & $75,01(41,47-122,16)$ & $76,11 \pm 18,93$ & $85,39(24,79-131,17)$ & $84,41 \pm 22,28$ & $0,073^{\mathrm{b}}$ \\
\hline Tingkat kecukupan zat besi (\%) & $25,08(16,71-190,5)$ & $54,51 \pm 45,82$ & $84,14(11,17-193)$ & $85,06 \pm 40,62$ & $0,000^{\mathrm{a}}$ \\
\hline Tingkat kecukupan vitamin $\mathrm{C}(\%)$ & $49,96(10,76-179,39)$ & $59,00 \pm 38,59$ & $61,03(7,93-339,06)$ & $93,12 \pm 73,15$ & $0,002^{\mathrm{a}}$ \\
\hline
\end{tabular}

Keterangan : ${ }^{\mathrm{a}}$ Uji Mann-Whitney, ${ }^{\mathrm{b}}$ independent T-test

Tabel 2. Karakteristik Responden berdasarkan Pendidikan dan Pekerjaan antara Kelompok Anemia dan Tidak Anemia

\begin{tabular}{lcc}
\hline \multicolumn{1}{c}{ Karakteristik } & Anemia $(\mathbf{n = 4 1})$ & Tidak Anemia $(\mathbf{n}=\mathbf{4 1})$ \\
\hline Pendidikan ibu, $\mathrm{n}(\%)$ & & $\boldsymbol{p}$ \\
1. Tidak sekolah & $2(4,9)$ & $2(4,9)$ \\
2. Tingkat dasar & $32(78,0)$ & $32(78,0)$ \\
3. Tingkat lanjut & $7(17,1)$ & $7(17,1)$ \\
Pekerjaan ibu, $(\%)$ & & \\
1. Tidak bekerja & $30(73,2)$ & $30(73,2)$ \\
2. Petani & $8(19,5)$ & $7(17,1)$ \\
3. Swasta & $3(7,3)$ & $4(9,8)$ \\
Pekerjaan kepala keluarga, $\mathrm{n}(\%)$ & & \\
1. Petani & $16(39,0)$ & $14(34,1)$ \\
2. Nelayan & $3(7,3)$ & $5(12,2)$ \\
3. Swasta & $22(53,7)$ & $22(53,7)$ \\
\hline Keterangan : ${ }^{\mathrm{a}}$ Uji Chi-square & & $0,901^{\mathrm{a}}$ \\
\end{tabular}


Tabel 3. Hubungan Riwayat Paparan Pestisida dan Tingkat Kecukupan Gizi dengan Kejadian Anemia

\begin{tabular}{|c|c|c|c|c|c|}
\hline Variab & & $\begin{array}{c}\text { Anemia } \\
(n=41)\end{array}$ & $\begin{array}{c}\text { Tidak } \\
\text { Anemia } \\
(n=41) \\
\end{array}$ & $p$ & OR $(95 \% \mathrm{CI})$ \\
\hline \multirow{2}{*}{ Riwayat paparan pestisida } & Terpapar & $30(73,2)$ & $15(36,6)$ & 0,002 & $4,7(1,85-12,08)$ \\
\hline & Tidak terpapar & $11(26,8)$ & $26(63,4)$ & & \\
\hline \multirow[t]{2}{*}{ Tingkat kecukupan protein } & Kurang $(<80 \%$ AKG $)$ & $26(63,4)$ & $15(36,6)$ & 0,027 & $3,0(1,22-7,38)$ \\
\hline & Baik $(\geq 80 \%$ AKG) & $15(36,3)$ & $26(63,4)$ & & \\
\hline \multirow[t]{2}{*}{ Tingkat kecukupan zat besi } & Kurang $(<77 \%$ AKG) & $30(73,2)$ & $17(41,5)$ & 0,007 & $3,8(1,52-9,75)$ \\
\hline & Baik $(\geq 77 \%$ AKG $)$ & $11(26,8)$ & $24(58,5)$ & & \\
\hline \multirow[t]{2}{*}{ Tingkat kecukupan vitamin $\mathrm{C}$} & Kurang $(<77 \%$ AKG) & $33(80,5)$ & $22(53,7)$ & 0,019 & $3,6(1,33-9,56)$ \\
\hline & Baik $(\geq 77 \%$ AKG) & $8(19,5)$ & $19(46,3)$ & & \\
\hline
\end{tabular}

Tabel 3 menunjukkan bahwa proporsi ibu hamil yang terpapar pestisida lebih besar pada kelompok anemia $(73,2 \%)$ dibanding pada kelompok tidak anemia $(36,6 \%)$. Hasil uji statistik terlihat bahwa ada hubungan riwayat paparan pestisida dengan kejadian anemia pada ibu hamil dengan nilai $p=0,002(\mathrm{OR}=4,7 ; 95 \% \mathrm{CI}=$ 1,85-12,08). Proporsi ibu hamil dengan tingkat kecukupan protein kurang, lebih besar pada kelompok anemia $(63,4 \%)$ dibandingkan dengan kelompok tidak anemia $(36,6 \%)$. Ada hubungan tingkat kecukupan protein dengan kejadian anemia pada ibu hamil, dengan nilai $p=0,027(\mathrm{OR}=3,0 ; 95 \% \mathrm{CI}=1,22-7,38)$.

Proporsi ibu hamil dengan tingkat kecukupan zat besi kurang, lebih besar pada kelompok anemia $(73,2 \%)$ dibandingkan dengan kelompok tidak anemia (41,5\%). Ada hubungan tingkat kecukupan zat besi dengan kejadian anemia pada ibu hamil dengan nilai $p=0,007$ $(\mathrm{OR}=3,8 ; 95 \% \mathrm{CI}=1,52-9,75)$. Proporsi ibu hamil dengan tingkat kecukupan vitamin $\mathrm{C}$ kurang, lebih besar pada kelompok anemia (80,5\%) dibanding pada kelompok tidak anemia $(53,7 \%)$. Selain itu, terdapat hubungan tingkat kecukupan vitamin $\mathrm{C}$ dengan kejadian anemia pada ibu hamil dengan nilai $p=0,019(\mathrm{OR}=3,6$; 95\% CI $=1,33-9,56$ ).

Analisis regresi logistik multivariat dilakukan untuk menentukan variabel yang dominan sebagai faktor risiko kejadian anemia pada ibu hamil. Berdasarkan analisis bivariat didapatkan empat variabel yang mempunyai nilai $p<0,25$ dan memenuhi syarat masuk ke dalam model multivariat yaitu variabel riwayat paparan pestisida, tingkat kecukupan protein, tingkat kecukupan zat besi dan tingkat kecukupan vitamin C.

Tabel 4. Hasil Uji Regresi Logistik Faktor Risiko yang Mempengaruhi Kejadian Anemia pada Ibu Hamil

\begin{tabular}{lccccccc}
\hline \multicolumn{1}{c}{ Variabel } & B & S.E & Wald & df & $\boldsymbol{p}$ & OR & 95\% CI \\
\hline Riwayat paparan pestisida & 1,589 & 0,524 & 9,190 & 1 & 0,002 & 4,9 & $1,75-13,67$ \\
Tingkat kecukupan zat besi & 1,090 & 0,524 & 4,333 & 1 & 0,037 & 2,9 & $1,06-8,29$ \\
Tingkat kecukupan vitamin C & 1,216 & 0,569 & 4,578 & 1 & 0,032 & 3,4 & $1,10-10,28$ \\
Konstanta & $-2,343$ & 0,654 & 12,830 & & 0,000 & 0,096 &
\end{tabular}

Hasil analisis multivariat menunjukkan bahwa riwayat paparan pestisida $(\mathrm{OR}=4,9,95 \% \mathrm{CI}: 1,75$ 13,67), tingkat kecukupan zat besi (OR=2,9, 95\% CI:1,06-8,29) dan tingkat kecukupan vitamin C $(\mathrm{OR}=3,4,95 \%$ CI:1,10-10,28) merupakan faktor risiko kejadian anemia pada ibu hamil di daerah pertanian Kabupaten Brebes.

\section{PEMBAHASAN}

Karakteristik responden yang meliputi umur kehamilan, pendidikan ibu, pekerjaan ibu dan pekerjaan kepala keluarga tidak berbeda bermakna antara kelompok anemia dan kelompok tidak anemia. Hal ini karena penelitian dilakukan pada tempat dan kondisi yang homogen yaitu di daerah pertanian. Kabupaten Brebes mengandalkan sektor pertanian terutama bawang merah yang memerlukan penyemprotan pestisida. Pestisida merupakan bahan kimia yang bersifat biosida (racun bagi manusia dan organisme lain) termasuk dalam kategori Bahan Beracun Berbahaya (B3) yang memiliki kemampuan untuk tidak mudah hilang sehingga sifat yang ditinggalkan akibat penggunaan pestisida akan mempengaruhi kesehatan manusia dan lingkungan. ${ }^{19}$

Hasil penelitian menunjukkan bahwa adanya riwayat paparan pestisida mempunyai risiko 4,9 kali untuk mengalami anemia dibanding ibu hamil tanpa riwayat paparan pestisida. Penelitian ini sesuai dengan penelitian pada petani hortikultura di Kabupaten Pemalang bahwa paparan pestisida mempunyai kecenderungan 5,3 kali lebih besar berpengaruh terhadap kejadian anemia bila dibandingkan dengan yang tidak terpapar pestisida. ${ }^{17}$ Hasil penelitian di daerah pertanian di negara India dan Filipina juga membuktikan bahwa parameter hematologi seperti Hemoglobin $(\mathrm{Hb})$, Hematokrit (Ht), Red Blood Cell (RBC) dan White Blood Cell (WBC) secara signifikan menurun pada kelompok 
terpapar pestisida dibandingkan dengan kelompok tidak terpapar pestisida. ${ }^{15,20}$

Dampak negatif dari paparan pestisida dapat mempengaruhi kesehatan ibu dalam hal ini berkaitan dengan keterlibatan ibu hamil baik secara langsung ataupun tidak langsung dalam kegiatan pertanian. Pestisida yang digunakan dalam pertanian di Brebes diantaranya adalah pestisida golongan organofosfat. Pestisida masuk dalam tubuh melalui beberapa cara, antara lain melalui kulit, mulut atau oral dan melalui pernafasan (inhalasi). Ibu hamil yang bekerja sebagai petani atau kepala keluarga yang bekerja sebagai petani akan mengakibatkan mereka terpapar pestisida, misalnya pada saat petani menyemprot pestisida di lahan pertanian sementara disaat yang sama ibu hamil sedang mencabut rumput/tanaman pengganggu, mencari hama, atau pada saat ibu hamil mencuci pakaian kotor yang selesai dipakai bertani, hal ini memungkinkan ibu tersebut terpapar pestisida yang menempel pada pakaian. Selain itu ibu hamil juga bisa terpapar pestisida yang terbawa pada kulit bawang saat panen atau melepaskan bawang dari tangkainya. Paparan pestisida pada ibu hamil juga bersumber dari lingkungan sekitar tempat tinggal seperti penyimpanan pestisida dan hasil panen di dalam rumah, serta tetangga yang menyimpan hasil panen di sekitar rumah. Hal ini dapat menyebabkan terakumulasinya paparan pestisida dalam tubuh ibu hamil sehingga menyebabkan anemia.

Tubuh yang terpapar pestisida dalam jangka waktu yang lama dapat menyebabkan keracunan yang dapat bersifat kronis mempengaruhi kerja sistem organ seperti syaraf, sistem hormonal dan sistem kekebalan tubuh. ${ }^{21}$ Beberapa jenis pestisida yang digunakan dalam pertanian termasuk golongan Endocrine Disrupting Chemicals (EDCs) yaitu senyawa-senyawa kimia berada di lingkungan yang mengganggu sintesis, sekresi, transpor, metabolisme, aksi pengikatan dan penghapusan hormon alami yang berfungsi untuk menjaga homeostasis, reproduksi dan proses tumbuh kembang. ${ }^{14}$ Anemia dapat terjadi pada orang yang terpapar pestisida, hal ini karena sulfhemoglobin dan methemoglobin yang terbentuk dalam sel darah merah. Sulfhemoglobin adalah bentuk hemoglobin yang di dalamnya berikatan dengan atom sulfur. Methemoglobin terbentuk pada saat zat besi dalam hemoglobin teroksidasi dari ferro menjadi ferri, selain hal tersebut juga terjadi ikatan nitrit dengan hemoglobin yang menjadi methemoglobin serta menyebabkan hemoglobin tidak dapat mengikat oksigen. Adanya sulfhemoglobin dan methemoglobin yang berada dalam darah mengakibatkan penurunan kadar hemoglobin dalam sel darah merah yang mengakibatkan terjadinya anemia. ${ }^{16}$

Anemia pada kehamilan dapat dicegah apabila seorang ibu memiliki asupan gizi yang baik sebelum dan selama hamil. Beberapa zat gizi memegang peran penting dalam pembentukan sel darah merah seperti protein, zat besi serta vitamin C. ${ }^{9}$ Rata-rata tingkat kecukupan protein pada kelompok anemia $(76,11 \%)$ lebih rendah dibandingkan pada kelompok tidak anemia $(84,41 \%)$. Tabel 3 menunjukkan ada hubungan tingkat kecukupan protein dengan kejadian anemia pada ibu hamil. Hasil penelitian di Deli Serdang juga menyatakan bahwa ada hubungan asupan protein dengan status anemia pada ibu hamil $(\mathrm{p}=0,001) .{ }^{22}$ Hasil pada penelitian ini menunjukkan, ibu hamil pada kelompok anemia lebih sering mengkonsumsi protein nabati seperti mengonsumsi tahu dan tempe, yaitu sebesar 97,56\%, sedangkan protein hewani seperti daging ayam $(34,14 \%)$, ikan $(30,24 \%)$ dan telur $(43,90 \%)$. Protein nabati mempunyai daya serap yang rendah dibandingkan dengan protein hewani. Protein hewani mempunyai kandungan asam amino esensial lengkap serta daya cerna tinggi sehingga jumlah yang diserap tubuh juga tinggi.

Protein merupakan makronutrien yang memiliki peran dalam penyimpanan, transportasi dan penyerapan zat besi $(\mathrm{Fe})$. Protein dapat meningkatkan penyerapan zat besi non-heme khususnya protein hewani, gugus sulfur yang berada dalam protein memiliki efek pemacu, gugus sulfur ini mengikat besi non- heme serta membantu penyerapannya di dalam tubuh. Protein bersama dengan zat besi menyusun hemoglobin. Protein juga berperan dalam transportasi zat besi dalam bentuk transferin. ${ }^{23}$ Berkurangnya asupan protein, dapat menyebabkan proses pengiriman zat besi terhambat, akibatnya menimbulkan defisiensi zat besi dengan ditandai menurunnya kadar hemoglobin di bawah nilai normal, sehingga menyebabkan anemia. ${ }^{24}$

Zat besi sebagai salah satu unsur pembentukan sel darah merah yang membawa oksigen ke seluruh jaringan tubuh. Asupan zat besi yang kurang pada ibu hamil dapat menyebabkan produksi hemoglobin menurun, diikuti oleh pengiriman oksigen yang terganggu ke rahim, plasenta dan janin. Kekurangan zat besi dapat menimbulkan masalah anemia gizi besi. Ratarata tingkat kecukupan zat besi pada kelompok anemia $(54,52 \%)$ lebih rendah daripada kelompok tidak anemia $(85,06 \%)$. Tabel 4 menunjukkan bahwa ibu hamil dengan tingkat kecukupan zat besi kurang, memiliki risiko 2,9 kali lebih tinggi untuk mengalami anemia dibandingkan ibu hamil yang tercukupi tingkat zat besinya $(\mathrm{OR}=2,9,95 \% \mathrm{CI}=1,06-8,29)$. Hasil penelitian ini sejalan dengan penelitian pada ibu hamil di Banyumas yang menunjukkan bahwa ibu hamil yang kurang asupan zat besi memiliki risiko 3,2 kali menderita anemia. $^{25}$

Zat besi makanan terbagi menjadi besi hem dan non-heme. Sumber heme adalah hati, ikan, daging, dan unggas, sedangkan sumber non-heme adalah kacangkacangan, sereal, sayur dan buah. ${ }^{26}$ Kecukupan zat besi ibu hamil sebagian besar dari sumber nabati (non-heme) seperti tempe $(96,33 \%)$, tahu $(97,5 \%)$ dan sayuran $(71,95 \%)$. Hasil penelitian ibu hamil di Tangerang juga 
menyatakan bahwa kecukupan zat besi lebih banyak dipenuhi dari nasi dan kacang-kacangan dibandingkan dengan lauk hewani. ${ }^{27}$ Defisiensi zat besi dapat terjadi karena pola konsumsi makan masih didominasi dengan makanan nabati yang merupakan sumber zat besi tetapi sulit diserap. ${ }^{26}$ Selain itu, hambatan penyerapan zat besi dapat terjadi karena adanya gangguan proses di dalam tubuh. Penghambat penyerapan tersebut meliputi tanin, fitat dan serat pangan. Pola makan ibu hamil yang terbiasa minum teh 1-2 kali per hari sebanyak $70,73 \%$ dan 4,87\% ibu hamil minum kopi 1-2 kali per minggu dapat menghambat penyerapan zat besi.

Penyerapan zat besi dapat meningkat apabila mengkonsumsi makanan sumber vitamin $\mathrm{C}$ seperti buah dan sayuran. Rata-rata tingkat kecukupan vitamin $\mathrm{C}$ pada kelompok anemia sebesar 59,00\% dan pada kelompok tidak anemia sebesar 93,13\%. Hasil uji statistik terlihat bahwa terdapat hubungan tingkat kecukupan vitamin $\mathrm{C}$ dengan kejadian anemia pada ibu hamil dan merupakan faktor risiko kejadian anemia pada ibu hamil dengan OR $=3,4(95 \%$ CI $=1,10-10,28)$. Hasil penelitian $\mathrm{di}$ Kabupaten Maros menyatakan bahwa konsumsi vitamin $\mathrm{C}$ rendah berhubungan dengan status hemoglobin ibu hamil $(p=0,004) .^{28}$ Vitamin $C$ memiliki peran dalam penyerapan zat besi di usus serta mobilisasi dari penyimpanan dalam feritin. Selain itu vitamin $C$ juga meningkatkan penyerapan zat besi dari makanan nabati (non-heme) dan termasuk antioksidan yang melindungi sel darah merah dari radikal bebas. ${ }^{26}$

\section{SIMPULAN}

Adanya riwayat paparan pestisida dan kekurangan asupan zat gizi (zat besi dan vitamin C) pada ibu hamil merupakan faktor risiko kejadian anemia pada ibu hamil di daerah pertanian Kabupaten Brebes.

\section{SARAN}

Hasil penelitian merekomendasikan perlu dilakukan upaya peningkatan asupan sumber zat besi dan vitamin $\mathrm{C}$ bagi ibu hamil. Bagi petugas kesehatan dan penyuluh pertanian perlu melakukan penyuluhan secara intensif cara penggunaan dan penyimpanan pestisida secara baik dan benar dan perlu mengkaji ulang tentang perijinan/peredaran pestisida di masyarakat serta meningkatkan sosialisasi tentang dampak pestisida terhadap kesehatan terutama pada ibu hamil.

\section{DAFTAR PUSTAKA}

1. World Health Organization. WHA Global Nutrition Targets 2025: Anaemia Policy Brief. Geneva; 2014.

2. Badan Penelitian dan Pengembangan Kesehatan Kementerian Kesehatan RI. Riset Kesehatan Dasar
(Riskesdas) 2013. Jakarta; 2013.

3. Dinas Kesehatan Kabupaten Brebes. Data Anemia pada Ibu Hamil. Brebes; 2016.

4. Darawati M. Gizi Ibu Hamil. In: Hardinsyah dan Supariasa, editor. Ilmu Gizi Teori Dan Aplikasi. 1st ed. Jakarta: Penerbit Buku Kedokteran EGC; 2017. p. $170-90$.

5. Dinas Kesehatan Provinsi Jawa Tengah. Profil Kesehatan Provinsi Jawa Tengah Tahun 2016. Vol. 3511351. Semarang; 2016.

6. Jannah N. Buku Ajar Asuhan Kebidanan: Kehamilan. Yogyakarta: Penerbit ANDI; 2012.

7. Huang L, Purvarshi G, Wang S, Zhong L, Tang H. The Influence of Iron-deficiency Anemia during the Pregnancy on Preterm Birth and Birth Weight in South China. J Food Nutr Res. 2015;3(9):570-4.

8. de Benoist B, McLean E, Egli I, Cogswell M. Worldwide prevalence of anaemia 1993-2005. WHO Global Database on Anemia. Geneva; 2008.

9. Horowitz K, Ingardia C, Borgida A. Anemia in Pregnancy. Clin Lab Med. 2013;33(2):281-91.

10. Morsy N, Alhady S. Nutritional Status And SocioEconomic Conditions Influencing Prevalence Of Anaemia In Pregnant Women. Int J Sci Technol Res. 2014;3(7):54-60.

11. Kartini A. Riwayat Paparan Pestisida Sebagai Faktor Risiko Kejadian Stunting Pada Anak Sekolah Dasar Di Daerah Pertanian (Disertasi). Semarang: Universitas Diponegoro; 2017.

12. Ardiwinata AN, Nursyamsi D. Residu Pestisida di Sentra Produksi Padi di Jawa Tengah. Pangan. 2012;21(1):39-58.

13. Suhartono, Djokomoeljanto $\mathrm{S}$, Hadisaputro $\mathrm{S}$, Subagio HW, Kartini A, Suratman. Pajanan Pestisida Sebagai Faktor Risiko Hipotiroidisme pada Wanita Usia Subur di Daerah Pertanian. Media Med Indones. 2012;46:91-9.

14. Diamanti-kandarakis E, Bourguignon J, Giudice LC, Hauser R, Prins GS, Soto AM, et al. EndocrineDisrupting Chemicals: An Endocrine Society Scientific Statement. Endocr Rev. 2009;30(December):293-342.

15. Reddy P, Kanojia J. Clinico Pathological Effects of Pesticides Exposure on Farm Workers. DAV Int $\mathbf{J}$ Sci. 2012;1(2):119-21.

16. Caravati EM, McGuigan MA, MacGregor I, Dawson AH, Seifert SA, Schonwald $S$ et al. Medical Toxicology. Third Edit. Dart RC, editor. Philadelphia, USA: Lippincott Williams \& Wilkins, Wolters Kluwer Company; 2004. p. 90-7.

17. Kurniasih SA, Setiani O, Nugraheni SA. Faktorfaktor yang Terkait Paparan Pestisida dan Hubungannya dengan Kejadian Anemia pada Petani Hortikultura di Desa Gombong Kecamatan Belik Kabupaten Pemalang Jawa Tengah. J Kesehat Lingkung Indones. 2013;12(2):132-7. 
18. Peraturan Menteri Kesehatan RI No. 75 Tahun 2013. Angka Kecukupan Gizi yang Dianjurkan bagi Bangsa Indonesia. 2013.

19. Pertiwi G. Modul Dampak Pestisida Terhadap Kesehatan Dan Lingkungan. 2006.

20. Del Prado-Lu JL. Pesticide Exposure, Risk Factors And Health Problems Among Cutflower Farmers : A Cross Sectional Study. J Occup Med Toxicol. 2007;8:1-8.

21. D'Arcece LPG, Colus IM de S. Cytogenetic And Molecular Biomonitoring Of Agricultural Workers Exposed To Pesticides In Brazil. Teratog Carcinog Mutagen. 2000;20(3):161-70.

22. Sinaga E, Lubis Z, Siagian A. Hubungan Asupan Protein dan Zat Besi dengan Status Anemia pada Ibu Hamil di Desa Naga Timbul Kecamatan Tanjung Morawa Kabupaten Deli Serdang Tahun 2014. J Gizi, Kesehat Reproduksi dan Epidemiol. 2015;1(1):1-6.

23. Etcheverry P, Ms Hawthorne KM, Liang LK, Abrams SA, Griffin IJ. Effect of Beef and Soy Proteins on the Absorption of Non-Heme Iron and
Inorganic Zinc in Children. J Am Coll Nutr. 2006;25(1):34-40.

24. Almatsier. Prinsip Dasar Ilmu Gizi. Jakarta: PT. Gramedia Pustaka Utama; 2009.

25. Utomo APW, Nurdiati DS, Padmawati RS. Rendahnya asupan zat besi dan kepatuhan mengonsumsi tablet besi berhubungan dengan kejadian anemia pada ibu hamil di Wilayah Kerja Puskesmas I Kembaran, Banyumas. J Gizi dan Diet Indones. 2016;3(November):41-50.

26. Briawan D. Anemia Masalah Gizi pada Remaja Wanita. Jakarta: EGC; 2013.

27. Fitri YP, Briawan D, Tanziha I, Madanijah S. Tingkat Kecukupan dan Bioavailabilitas Asupan Zat Besi pada Ibu Hamil di Kota Tangerang. J MKMI. 2016;12(3):185-91.

28. Patimah S, Hadju V, Bahar B, Abdullah Z. Pola Konsumsi dan Kadar Hemoglobin pada Ibu Hamil di Kabupaten Maros, Sulawesi Selatan. Makara Kesehat. 2011;15(1):31-6. 